\title{
THE RELATIONSHIP BETWEEN MUSICAL INTELLIGENCE AND THE ENHANCEMENT OF MATHEMATICAL CONNECTION ABILITY USING ETHNOMATHEMATICS AND THE MOZART EFFECT
}

\author{
Dianne Amor Kusuma ${ }^{* 1}$, Estiyan Dwipriyoko ${ }^{2,3}$ \\ ${ }^{1}$ Universitas Padjadjaran, Indonesia \\ ${ }^{2}$ Universiti Tun Hussein-Onn Malaysia, Malaysia \\ ${ }^{3}$ Universitas Langlangbuana, Indonesia
}

\begin{tabular}{l} 
Article Info \\
\hline Article history: \\
Received Feb 26, 2021 \\
Revised Apr 16, 2021 \\
Accepted Apr 18, 2021 \\
\hline
\end{tabular}

\section{Keywords:}

Ethnomathematics, Mathematical connection, Mozart Effect,

Musical intelligence

\begin{abstract}
The background of this study is mathematics learning outcomes of junior high school students in agricultural areas are still low because they are less motivated to learn mathematics, so that is has an impact on their low learning outcomes. This study aims to find the relationship between musical intelligence and the enhancement of mathematical connection ability by applying Ethnomathematics and the Mozart Effect for increasing students' motivation to learn mathematics. This study used a quasi-experimental nonequivalent control group design in grade 7 students at SMPN Bojongsoang 1, Kabupaten Bandung. The instruments used were the test of mathematical connection ability, musical intelligence questionnaire, and observation sheets. The results showed that: (1) there were differences in mathematical connection ability of students who received Ethnomathematics and the Mozart Effect learning with students who received direct learning; (2) musical intelligence has a positive impact on the enhancement of students' mathematical connection ability; and (3) students have a positive attitude towards learning with application of Ethnomathematics and the Mozart Effect, and more motivated to learn mathematics. The conclusion of this study is that there is a relationship between musical intelligence and the enhancement of mathematical connection ability, and students are more motivated to learn mathematics. Implication of this research for future research and learning practice is that students' mathematical connection ability can be explored and improved in various ways, one of which is by applying Ethnomathematics and the Mozart Effect in mathematics learning, and can be influenced by many things, one of them is musical intelligence. Therefore, in future research, it would be recommended to study the relationship between musical intelligence and the enhancement of other mathematical abilities using Ethnomathematics and the Mozart Effect.
\end{abstract}

Copyright $@ 2021$ IKIP Siliwangi. All rights reserved.

\section{Corresponding Author:}

Dianne Amor Kusuma,

Department of Mathematics,

Faculty Mathematics and Natural Sciences,

Universitas Padjadjaran

Jl. Raya Bandung Sumedang Km. 21, Jatinangor, West Java 45361, Indonesia.

Email: amor@unpad.ac.id

\section{How to Cite:}

Kusuma, D. A., \& Dwipriyoko, E. (2021). The relationship between musical intelligence and the enhancement of mathematical connection ability using ethnomathematics and the Mozart effect. Infinity, 10(2), 191-202. 


\section{INTRODUCTION}

Most of students in any levels of education feel that mathematics is a difficult subject. The impact on their low motivation to learn. The low motivation of students can impact to their low learning outcomes (Kusuma, 2019a). The motivation to learn will emerge if students feel that what they are learning has benefits in real life. In other words, students will be motivated to learn if what they learn is related to their daily lives, so they feel the need and are interested for learning it. Students' interest in learning mathematics can be influenced by two things, namely: the relation of mathematics to their real life and culture, and their comfort when learning mathematics in class.

A preliminary study conducted through interviews with several mathematics teachers in several public junior high schools in the agricultural area of Bandung district shows that mathematics learning outcomes are still low because students do not understand the internal and external relationships of mathematics. In a sense, students do not understand the relationship between mathematical concepts and their procedures, mathematics and other fields, and the relationship between mathematics and everyday life, so they feel that mathematics is not useful in their lives.

The purpose of the mathematics learning process, besides changing student behavior, is to explore and improve mathematical abilities, one of which is mathematical connection. Mathematical connection ability needs to be improved so that students understand the following: (a) there is a relationship between mathematical concepts and its procedures; (b) mathematics has links with other fields; and (c) mathematics is useful in their daily life and culture (Rohendi \& Dulpaja, 2013). Therefore, it is necessary to apply a learning approach that can improve students' mathematical abilities and can make them feel comfortable when learning mathematics. In this study, the measured mathematical connection ability includes the following indicators: (1) linking mathematical concepts; (2) using one mathematical idea to understand another mathematical ideas; (3) using mathematics to solve problems in everyday life that contain local culture; and (4) exploring mathematical problems and describing the results with graphs, surrounding objects, and mathematical modeling.

Ethnomathematics is knowledge that links mathematics with cultural elements (d'Ambrosio, 1985). The form of the relationship can be seen from the aspect of applying mathematical concepts in a culture and how to teach mathematical concepts that are adapted to local culture and the uniqueness of the character of students (Kusuma, 2019b). Ethnomathematics is also a study that focuses on how to teach mathematical concepts in a cultural context (Orey \& Rosa, 2004). Thus, it is expected that students will feel that mathematics is part of their culture and are more motivated to learn mathematics. Implementation of Ethnomathematics in this research are: a) conducting a survey in Tegalluar Village, Bojongsoang, Bandung Regency, and conducting interviews with residents and community leaders in the village; b) compiling learning tools containing the culture of Tegalluar Village; c) carry out a learning process that includes the culture of Tegalluar Village; d) compile a research instrument containing the culture of Tegalluar Village.

In order for students to understand the material being taught, it is necessary to create a learning atmosphere that makes them feel comfortable and do not feel tense or pressured when learning mathematics. One way is to implement classical music into learning, because music can strengthen the brain's nervous system, can improve memory, and make students more focused. Music composed by Mozart (known as the Mozart Effect) is a classical music that can increase a person's intelligence (Stough et al., 1994; Verrusio et al., 2015). The composition of notes in Mozart's music can stimulate the performance of the forebrain in humans, which has a positive impact on reasoning abilities, so it is hoped that it can explore 
and improve students' mathematical connection skills and make them feel comfortable when studying mathematics. In this study, application of the Mozart Effect is combined with Ethnomathematics learning. The technical implementation, Mozart K. 448's music is played with the dynamics of mezzo piano (rather soft), frequency of 8000-32.000 hertz, and tempo of allegro con spirito (120-168 beat/minute) during learning activities, with amplitude settings that has been adjusted to capacity of the classroom and number of students. Application of the Mozart Effect is combined with Ethnomathematics learning because it have many advantages as follows: (a) Mozart K. 448's music that is played during mathematics learning activities can stimulate students' brains and facilitate the complex nervous system involved when students learn mathematics (Campbell, 2009), so that they can better understand the relationship between the mathematical concepts learned and their culture; and (b) Mozart K. 448's music can manipulate students' moods and improve their cognitive performance (Rauscher et al., 1993), thus making them more creative in finding relationships between mathematical concepts taught with their culture, and in providing examples of situations which is usually done in their culture which contains mathematical concepts.

Gardner (2011) suggests that everyone has different type of intelligence, some of which are mathematical logic intelligence and musical intelligence. Mathematical logic intelligence is ability to reason, recognize patterns, and logically analyze problems (Gardner, 2011). Musical intelligence is ability to recognize patterns, rhythms and sounds, and express musical forms (Widhianawati, 2011). The students' mathematics skills with high logicalmathematical and musical intelligence could meet all indicators of problem interpretation problems, solution applications, solution evaluation, and concluding results using facts (Rifqi et al., 2021). Mathematical logic intelligence and musical intelligence have one tendency in common, namely being able to think conceptually about patterns. Therefore, it is expected that musical intelligence can have an impact on increasing mathematical connection ability. In this study, indicators of musical intelligence that were measured as follows: (1) like playing a musical instrument; (2) can hum and sing; (3) easily recognize songs and memorize song lyrics; and (4) sensitive to tone and rhythm.

Studies related to students' mathematical connection ability have been conducted by several researchers, including: Hendriana et al. (2014), Noto et al. (2016), Siregar and Surya (2017), Haji et al. (2017), and Yaniawati et al. (2019). These studies showed that efforts have been made to improve students' mathematical connection abilities by applying various learning approaches. However, none of these studies has examined the impact of musical intelligence on students' mathematical connection ability.

So far, study on the implementation of Ethnomathematics in learning has been carried out by several researchers, including: Rubio (2016), Muhtadi et al. (2017), Kusuma, et al. (2017), Supiyati et al. (2019), Hartinah et al. (2019), Peni and Baba (2019), and Vitoria and Monawati (2020). In these studies, it shows that Ethnomathematics has been implemented in learning as an effort to improve student learning outcomes in mathematics. However, so far there has been no study that combines Ethnomathematics with the Mozart Effect. Because this study involves the Mozart Effect, researcher is interested to find the relationship between musical intelligence on enhancing certain mathematical abilities, namely mathematical connection ability. Studies related to the Mozart Effect have been conducted by Roth and Smith (2008), Taylor et al. (2012), Verusio et al. (2015), and Kusuma (2020).

Based on description above, problems of this study are: (1) Is mathematical connection ability of junior high school students who get Ethnomathematics and the Mozart Effect learning better than students who get direct learning? (2) How is the impact of musical intelligence on mathematical connection ability of junior high school students who learn 
mathematics by applying Ethnomathematics and the Mozart Effect? (3) How do students' attitude and motivation towards learning mathematics with application of Ethnomathematics and the Mozart Effect?

\section{METHOD}

The method research strategy used in this study was quasi experiment non equivalent control group. Research philosophy used in this study was positivism, because this is an objective research (Dwipriyoko, 2020). Research approaches used in this study was deductive, because scientific research based on theories. Research timeline used in this study was longitudinal, because historical time orientation is forward (Dwipriyoko \& Sari, 2021).

Data collection was conducted on two classes of the $7^{\text {th }}$ grade students of SMPN Bojongsoang 1 Bandung District, each class containing 30 students. Experimental class was treated with Ethnomathematics and the Mozart Effect (EM) learning, and control class was given Direct Learning (DL) treatment. Figure 1 shows the class condition of the 7th grade students of SMPN Bojongsoang 1 Bandung District.

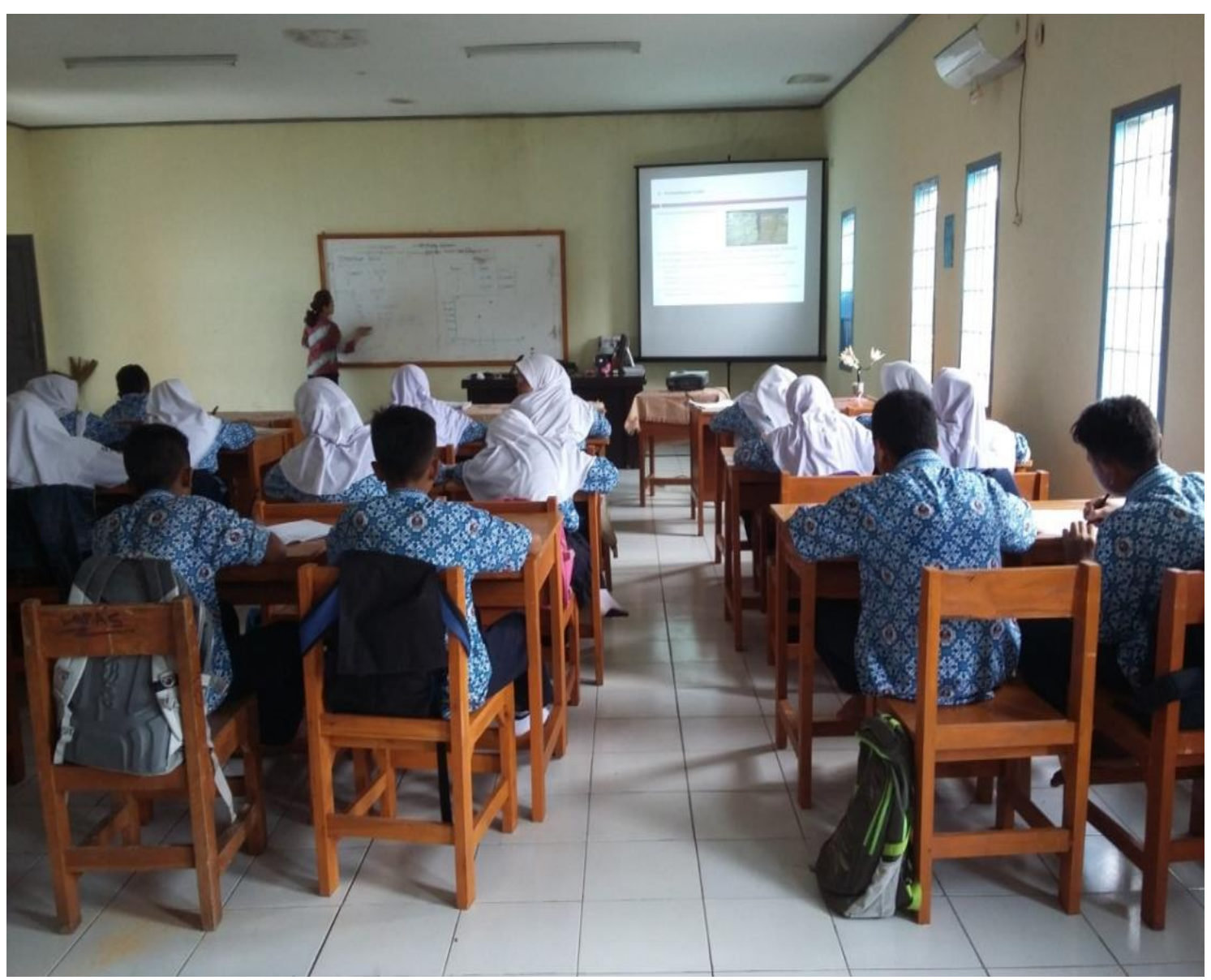

Figure 1. Students with Mozart's musical background

Research instruments used were mathematical connection ability test, musical intelligence questionnaire, and questionnaire on students' attitude towards learning Ethnomathematics and the Mozart Effect. The research instrument was tested before use, then it was analyzed. Results of testing validity of mathematical connection ability test items 
using Pearson Product Moment correlation formula show that all the items used are valid. This research is descriptive and inferential.

Data of mathematical connection ability test results were analyzed in the following steps: 1) normality test using One-Sample Kolmogorov Smirnov; 2) homogeneity test of variance using Levene statistical test; 3) hypothesis test using one way anova; 4) Normalized gain analysis, to determine the enhancement of mathematical connection ability of students who get EM and those who get DL; and 5) regression analysis, to determine the relationship between musical intelligence and the enhancement of mathematical connection ability. Data of musical intelligence questionnaire and students' attitude questionnaire on application of Ethnomathematics and the Mozart Effect in mathematics learning were analyzed descriptively.

\section{RESULTS AND DISCUSSION}

\subsection{Results of Mathematical Connection Ability Test Analysis}

Mathematical connection ability test was given at the first meeting (pretest) and the last meeting (post test) to experimental and control class students. Pretest questions are the same as post test, there are seven essay questions, with subject of social arithmetic. Pretest was given with the aim of determining students' initial ability of both classes in mathematical connections. Results of pretest showed that experimental class students got the highest score of 46 and the lowest was 21. Control class students got the highest score of 43 and the lowest was 25. Mean of experimental class students was 29.17 and control class was 31.23. Pretest descriptive statistics are presented in Table 1.

Table 1. Pretest descriptive statistics

\begin{tabular}{lccccc}
\hline & N & Minimum & Maximum & Mean & Std. Deviation \\
\hline Pretest_Experiment & 30 & 21 & 46 & 29.17 & 5.509 \\
Pretest_Control & 30 & 25 & 43 & 31.23 & 4.853 \\
Valid N (listwise) & 30 & & & & \\
\hline
\end{tabular}

After normality and homogeneity test were carried out and it was stated that two sample groups were normally distributed and homogeneous, then mean difference test of initial mathematical connection ability was carried out using one-way anova. Results of initial ability mean difference test are presented in Table 2.

Table 2. Result of mean difference test of initial mathematical connection ability

\begin{tabular}{lccccc}
\hline & Sum of Square & df & Mean Square & F & Sig. \\
\hline Between Groups & 64.067 & 1 & 64.067 & 2.335 & 0.132 \\
Within Groups & 1591.533 & 58 & 27.440 & & \\
Toal & 1655.600 & 59 & & & \\
\hline
\end{tabular}

Table 2 show the p-value of $0.132>\alpha$, so there is no mean difference between initial mathematical connection ability of experimental class and control class students. After the treatment was given to students of experimental class (EM) and students of control class (DL) for five lectures, students of both classes were given post test of their mathematical 
connection ability. The test is given with aim of seeing the impact of EM and DL treatment on students' mathematical connection abilities. Results of post test showed that the highest score achieved by experimental class students was 95 and the lowest score was 35 . The highest score achieved by control class students was 67 and the lowest was 33. Mean achieved by experimental class students was 61.57 and control class was 49.50. Descriptive statistics in detail can be seen in Table 3.

Table 3. Post test descriptive statistics

\begin{tabular}{lccccc}
\hline & N & Minimum & Maximum & Mean & Std. Deviation \\
\hline Post test_Experiment & 30 & 35 & 95 & 61.57 & 18.822 \\
Post test_Control & 30 & 33 & 67 & 49.50 & 10.312 \\
Valid N (listwise) & 30 & & & & \\
\hline
\end{tabular}

After normality and homogeneity test were carried out and it was stated that two sample groups were normally distributed and homogeneous, mean difference test of mathematical connection ability was carried out using one-way anova. Results of post test mean difference test are presented in Table 4.

Table 4. Result of mean difference test of mathematical connection ability

\begin{tabular}{lccccc}
\hline & Sum of Square & df & Mean Square & F & Sig. \\
\hline Between Groups & 2184.067 & 1 & 2184.067 & 9.484 & 0.003 \\
Within Groups & 13356.867 & 58 & 230.291 & & \\
Toal & 15540.933 & 59 & & & \\
\hline
\end{tabular}

Table 4 show the p-value is $0.003<\alpha$, so there is mean difference between mathematical connection ability of experimental class students and control class students. That is, mathematical connection ability of students who get ethnomathematics and the Mozart Effect with students who receive direct learning is significantly different.

\subsection{Results of Normalized Gain Analysis}

Normalized gain analysis was carried out to determine the enhancement of mathematical connection ability of experimental class students (EM) and control class students (DL). Table 5 presents descriptive statistics of normalized gain.

Table 5. Descriptive statistics of normalized gain

\begin{tabular}{lccccc}
\hline & N & Minimum & Maximum & Mean & Std. Deviation \\
\hline Gain_Experiment & 30 & 0.16 & 0.91 & 0.4738 & 0.23098 \\
Gain_Control & 30 & 0.11 & 0.42 & 0.2719 & 0.10213 \\
Valid N (listwise) & 30 & & & & \\
\hline
\end{tabular}

Table 5 showed that mean gain of experimental class is 0.4738 and control class is 0.2719. It means, there is a tendency that implementation of Ethnomathematics and the Mozart Effect in mathematics learning increases the variability of students' mathematical connection ability. 
After normality and homogeneity test were carried out, and it was stated that two sample groups were normally distributed and homogeneous, then mean difference test of normalized gain was carried out using one-way anova. Results of mean difference test of normalized gain are presented in Table 6.

Table 6. Result of mean difference test of normalized gain

\begin{tabular}{lccccc}
\hline & Sum of Square & df & Mean Square & F & Sig. \\
\hline Between Groups & 0.611 & 1 & 0.611 & 19.167 & 0.000 \\
Within Groups & 1.850 & 58 & 0.032 & & \\
Toal & 2.461 & 59 & & & \\
\hline
\end{tabular}

Table 6 showed that the p-value (sig.) is $0.000<\alpha$, there is mean difference between gain of mathematical connection ability of experimental class students and control class students. Therefore, it can be said that gain (enhancement) of students'mathematical connection ability who get learning Ethnomathematics and the Mozart Effect, with students who get direct learning, is significantly different. The enhancement of mathematical connection ability achieved by students who get Ethnomathematics learning and the Mozart Effect (EM) is due to EM can stimulate the brain to compose patterns that produce meaning by linking the concepts learned with real life experienced by students (Johnson, 2002). In addition, application of the Mozart Effect in mathematics learning strengthen the brain nervous system, so it can improve memory and make students more focus on material taught by the teacher.

\subsection{Results of Musical Intelligence Questionnaire Analysis}

Experimental class students are asked to fill out a Likert scale questionnaire after all learning activities on the subject of social arithmetic have been completed and post test have been carried out, to find out the impact of musical intelligence on mathematical connection ability of students who get Ethnomathematics and the Mozart Effect learning. The questionnaire contains 30 statements. Results of students' musical intelligence questionnaire analysis are presented in Table 7.

Table 7. Results of musical intelligence questionnaire analysis

\begin{tabular}{|c|c|c|c|c|c|c|}
\hline \multirow{2}{*}{\multicolumn{2}{|c|}{ Model }} & \multicolumn{2}{|c|}{ Unstandardized Coeff. } & \multirow{2}{*}{$\begin{array}{c}\text { Unstandardized } \\
\text { Coeff. Beta }\end{array}$} & \multirow{2}{*}{$\mathbf{t}$} & \multirow{2}{*}{ Sig. } \\
\hline & & B & Std. Error & & & \\
\hline \multirow[t]{2}{*}{1} & (Constant) & -33.656 & 4.571 & & -7.363 & 0.000 \\
\hline & Musical Int & 1.438 & 0.068 & 0.970 & 21.199 & 0.000 \\
\hline
\end{tabular}

Table 7 showed that regression coefficient is 1.438 , so it can be said that musical intelligence has positive impact on students' mathematical connection ability. Because the p-value (sig.) is $0.000<\alpha$, there is an effect of musical intelligence on students' mathematical connection ability. This results match with Rifqi et al. (2021) article about mathematics skills with high logical-mathematical and musical intelligence could be related. 


\subsection{Results of Students' Attitude Questionnaire Analysis}

For obtaining information about students' attitude towards learning mathematics using Ethnomathematics and the Mozart Effect (EM), experimental class students were asked to fill out a Likert scale questionnaire. The questionnaire contains 30 statements and is given after all learning activities have been completed. Recapitulation of results of students' attitude questionnaire analysis is presented in Table 8.

Table 8. Recapitulation of results of students' attitude questionnaire analysis

\begin{tabular}{cc}
\hline Score & Frequency \\
\hline $80.00-86.00$ & 5 \\
$87.00-92.00$ & 8 \\
$93.00-98.00$ & 14 \\
$99.00-104.00$ & 3 \\
\hline Sum & 30 \\
Mean Score & 92.42 \\
\hline
\end{tabular}

Table 8 show that those who get scores between 93 and 98 (from maximum score of 120) are almost half of experimental class students. Mean score achieved by students of experimental class was 92.42. It means, students have positive attitude towards learning mathematics by applying Ethnomathematics and the Mozart Effect. These results are supported by the findings of Ponte et al. (1994) that students' attitudes in learning mathematics are one of the factors that underlie student achievement in mathematics, so student achievement is also influenced by student attitude towards learning.

\section{CONCLUSION}

Mathematical connection is one of mathematical abilities that exist in every students, which must be explored and developed. This ability can be explored and developed by applying appropriate learning approaches and in accordance with academic ability and cognitive development of students. Based on the results of research and discussion, it was found that mathematical connection ability of junior high school students who received Ethnomathematics and the Mozart Effect learning was better than students who received direct learning. It can be seen from post test mean score of experimental class which is greater than control class, and gain average of experimental class is greater than control class.

Because mathematical logic intelligence and musical intelligence have one tendency in common, namely being able to think conceptually about patterns, it is necessary to study more deeply the impact of musical intelligence on students' mathematical connection ability when they learn mathematics by applying Ethnomathematics and the Mozart Effect. Results showed that musical intelligence has a positive impact on mathematical connection ability of junior high school students. It means, there is a relationship between musical intelligence and the enhancement of mathematical connection ability.

Students' achievement in mathematics is influenced by several factors, one of which is students' attitude and motivation towards learning. Students' attitude and motivation regarding emotions related to mathematics and their beliefs in mathematics. The results of this study indicate that students have a positive attitude and more motivated towards learning with application of Ethnomathematics and the Mozart Effect. 


\section{ACKNOWLEDGMENTS}

The author would like to thank the Center of Science and Technology Studies of FMIPA Unpad for providing support in this research, also to Mr. Cucu Dermawan, S.Pd., M.M.Pd. as the Principal of SMPN 1 Bojongsoang, Bandung District, and Mrs. Dra. Siti Sa'adah, M.M.Pd. as mathematics teacher, who has helped and facilitated the researcher.

\section{REFERENCES}

Campbell, D. (2009). The Mozart effect: Tapping the power of music to heal the body, strengthen the mind, and unlock the creative spirit. New York: Harper Collins.

d'Ambrosio, U. (1985). Ethnomathematics and its place in the history and pedagogy of mathematics. For the learning of Mathematics, 5(1), 44-48.

Dwipriyoko, E. (2020). Partial Business Process Re-engineering in New Generation Cooperatives Enterprise Architecture Implementation. Journal of Physics: Conference Series, 1477(5), 052033. https://doi.org/10.1088/1742$6596 / 1477 / 5 / 052033$

Dwipriyoko, E., \& Sari, W. P. (2021). Wireless scoreboard technology architecture for athlete performance data warehouse at multiple table sports games. Journal of Physics: Conference Series, 1764(1), 012058. https://doi.org/10.1088/17426596/1764/1/012058

Gardner, H. E. (2011). Frames of mind: The theory of multiple intelligences. Hachette Uk.

Hendriana, H., Slamet, U. R., \& Sumarmo, U. (2014). Mathematical connection ability and self-confidence (an experiment on junior high school students through contextual teaching and learning with mathematical manipulative). International Journal of Education, 8(1), 1-11.

Haji, S., Abdullah, M. I., Maizora, S., \& Yumiati, Y. (2017). Developing students'ability of mathematical connection through using outdoor mathematics learning. Infinity Journal, 6(1), 11-20. https://doi.org/10.22460/infinity.v6i1.p11-20

Hartinah, S., Suherman, S., Syazali, M., Efendi, H., Junaidi, R., Jermsittiparsert, K., \& Rofiqul, U. M. A. M. (2019). Probing-prompting based on ethnomathematics learning model: the effect on mathematical communication skill. Journal for the Education of Gifted Young Scientists, 7(4), 799-814. https://doi.org/10.17478/jegys.574275

Johnson, E. B. (2002). Contextual teaching and learning: What it is and why it's here to stay. California: Corwin Press.

Muhtadi, D., Sukirwan, S., Warsito, W., \& Prahmana, R. C. I. (2017). Sundanese Ethnomathematics: Mathematical Activities in Estimating, Measuring, and Making Patterns. Journal on Mathematics Education, 8(2), 185-198. https://doi.org/10.22342/jme.8.2.4055.185-198

Kusuma, D. A., Dewanto, S. P., Ruchjana, B. N., \& Abdullah, A. S. (2017). The role of ethnomathematics in West Java (a preliminary analysis of case study in Cipatujah). Journal of Physics: Conference Series, 893(1), 012020. https://doi.org/10.1088/1742-6596/893/1/012020 
Kusuma, D. A. (2019a). Peningkatan komunikasi matematis siswa menggunakan pembelajaran kontekstual berbasis etnomatematika dengan penerapan mozart effect (studi eksperimen terhadap siswa sekolah menengah pertama). Teorema: Teori dan Riset Matematika, 4(1), 65-74. https://doi.org/10.25157/teorema.v4i1.1954

Kusuma, D. A. (2019b). Penerapan ethnomathematics dan hypnoteaching pada mata kuliah matematika kimia. JNPM (Jurnal Nasional Pendidikan Matematika), 3(2), 165-176.

Kusuma, D. A. (2020). Peningkatan representasi matematis menggunakan pembelajaran ethnomathematics dengan penerapan mozart effect. IndoMath: Indonesia Mathematics Education, 3(1), 10-19. https://doi.org/10.30738/indomath.v3i1.6286

Noto, M. S., Hartono, W., \& Sundawan, D. (2016). Analysis of students mathematical representation and connection on analytical geometry subject. Infinity Journal, 5(2), 99-108. https://doi.org/10.22460/infinity.v5i2.p99-108

Orey, D., \& Rosa, M. (2004). Ethnomathematics and the teaching and learning mathematics from a multicultural perspective. Ethnomathematics and mathematics education. Proceedings of the $10^{\text {th }}$ International Congress of Mathematics Education Copenhagen, 139-148.

Peni, N. R. N., \& Baba, T. (2019). Consideration of curriculum approaches of employing ethnomathematics in mathematics classroom. Journal of Physics: Conference Series, 1321(3), 032125. https://doi.org/10.1088/1742-6596/1321/3/032125

Ponte, J. P., Matos, J. F., Guimarães, H. M., Leal, L. C., \& Canavarro, A. P. (1994). Teachers' and students' views and attitudes towards a new mathematics curriculum: A case study. Educational Studies in Mathematics, 26(4), 347-365. https://doi.org/10.1007/BF01279520

Rauscher, F. H., Shaw, G. L., \& Ky, C. N. (1993). Music and spatial task performance. Nature, 365(6447), 611-611. https://doi.org/10.1038/365611a0

Roth, E. A., \& Smith, K. H. (2008). The Mozart effect: evidence for the arousal hypothesis. Perceptual and motor skills, 107(2), 396-402. https://doi.org/10.2466/pms.107.2.396-402

Rohendi, D., \& Dulpaja, J. (2013). Connected Mathematics Project (CMP) model based on presentation media to the mathematical connection ability of junior high school student. Journal of education and practice, 4(4), 17-22.

Rifqi, A., Rochmad, R., \& Suyitno, H. (2021). Critical Thinking Skills Reviewed from Logical-Mathematical and Musical Intelligence on Process Oriented Guided Inquiry Learning. Unnes Journal of Mathematics Education Research, 10(A), 175-183.

Rubio, J. S. (2016). The Ethnomathematics of the Kabihug Tribe in Jose Panganiban, Camarines Norte, Philippines. Malaysian journal of mathematical sciences, 10, 211231.

Stough, C., Kerkin, B., Bates, T., \& Mangan, G. (1994). Music and spatial IQ. Personality and Individual Differences, 17(5), 695. https://doi.org/10.1016/01918869(94)90145-7

Supiyati, S., Hanum, F., \& Jailani, J. (2019). Ethnomathematics in Sasaknese Architecture. Journal on Mathematics Education, 10(1), 47-58. https://doi.org/10.22342/jme.10.1.5383.47-58 
Taylor, J. M., \& Rowe, B. J. (2012). The "Mozart Effect" and the mathematical connection. Journal of College Reading and Learning,42(2), 51-66. https://doi.org/10.1080/10790195.2012.10850354

Siregar, N. D., \& Surya, E. (2017). Analysis of students' junior high school mathematical connection ability. International Journal of Sciences: Basic and Applied Research (IJSBAR), 33(2), 309-320.

Verrusio, W., Moscucci, F., Cacciafesta, M., \& Gueli, N. (2015). Mozart effect and its clinical applications: A review. Journal of Advances in Medicine and Medical Research, 8(8), 639-650. https://doi.org/10.9734/BJMMR/2015/17192

Vitoria, L., \& Monawati, M. (2020). Developing ethnomathematics-based worksheet to teach linear equations. Journal of Physics: Conference Series, 1460(1), 012021. https://doi.org/10.1088/1742-6596/1460/1/012021

Widhianawati, N. (2011). Pengaruh pembelajaran gerak dan lagu dalam meningkatkan kecerdasan musikal dan kecerdasan kinestetik anak usia dini. Jurnal Penelitian Pendidikan, 2, 220-228.

Yaniawati, R. P., Indrawan, R., \& Setiawan, G. (2019). Core model on improving mathematical communication and connection, analysis of students' mathematical disposition. International Journal of Instruction, 12(4), 639-654. https://doi.org/10.29333/iji.2019.12441a 
